\title{
Prey preferences of blue crabs Callinectes sapidus feeding on three bivalve species
}

\author{
Elizabeth L. Ebersole*, Victor S. Kennedy** \\ University of Maryland System, Horn Point Environmental Laboratory, PO Box 775, Cambridge, Maryland 21613, USA
}

\begin{abstract}
Individual blue crabs Callinectes sapidus were allowed to forage on 3 bivalve species (soft clam Mya arenaria; Atlantic rangia clam Rangia cuneata; hooked mussel Ischadium recurvum), with 2 of the 3 species made available together at one time in 2201 aquaria. In 3 separate sets of experiments, we examined the blue crab's consumption and preferences between 2 bivalve species of different profitabilities [(net energy intake)/(handling time); $\mathrm{J} \mathrm{s}^{-1}$ ]: $M$. arenaria and $R$. cuneata, $M$. arenaria and $I$. recurvum, and $R$. cuneata and $I$. recurvum. These experiments also examined the effects of 3 additional factors on prey consumption and prey preference: prey location (near to or distant from point of introduction of crab), prey refuge availability (shallow or deep sand for the clams; detached or clustered for the hooked mussel), and prey density (high or low numbers). Profitability curves correctly predicted that the blue crab preferred the highly profitable soft clam over the less energetically profitable Atlantic rangia clam. When the difference between prey profitabilities was not as great (i.e. between the soft clam and the hooked mussel, and between the Atlantic rangia clam and the hooked mussel) profitability alone was not a clear predictor of blue crab preference. Prey refuge availability significantly affected prey preference; deep sand provided (1) a greater refuge for the soft clam than for the Atlantic rangia clam and (2) a greater refuge for the soft clam than clustering provided for the hooked mussel. Prey location and refuge availability interacted to affect prey preference, in that prey location significantly affected prey consumption in shallow sand (more near prey than distant prey were eaten). but not in deep sand. Prey density generally affected total prey consumption, but not prey preference.

KEY WORDS: Foraging Prey preferences - Blue crabs B Bivalves C Callinectes Mya $\cdot$ Rangia Ischadium
\end{abstract}

\section{INTRODUCTION}

The blue crab Callinectes sapidus Rathbun is a decapod common in Chesapeake Bay, USA, and native to the western Atlantic coast from Nova Scotia to Argentina (Laughlin 1982). Blue crabs are important predators that affect the diversity and structure of benthic communities, and they can control the distribution and abundance of populations of benthic species locally (Virnstein 1977, 1979, Laughlin 1982, Hines et al. 1990).

Prey profitability and prey refuges, such as burial depth, clustering, and prey density, affect prey mortal-

\footnotetext{
- Present address: ICF, Incorporated, 9300 Lee Highway,

Fairfax, Virginia 22031-1207, USA

-Addressee for correspondence
}

ity in benthic systems (Lipcius \& Hines 1986, Haddon et al. 1987, Eggleston 1990b). Examining prey preferences in light of prey refuges and profitabilities helps us to understand community dynamics, thus aiding the prediction of distribution and abundances of benthic species. As a generalist feeder (Laughlin 1982, Alexander 1986) with a wide variety of prey choices, any preference by the blue crab for one species over another could affect community dynamics.

We investigated blue crab preferences among 2 infaunal and 1 epifaunal bivalve species that are readily eaten by blue crabs: the infaunal soft clam Mya arenaria, the infaunal Atlantic rangia clam Rangia cuneata, and the epifaunal hooked mussel Ischadium recurvum. The soft clam has a thin brittle shell and lives buried in the sand in mesohaline and polyhaline regions of Chesapeake Bay. Newly settled spat occur in the upper $2 \mathrm{~cm}$ of the sediment, whereas older, 
larger clams can bury up to $25 \mathrm{~cm}$ deep (Blundon \& Kennedy 1982b, Hines \& Comtois 1985). The Atlantic rangia clam is a thick-shelled clam that buries within the top $5 \mathrm{~cm}$ of the sediment surface in the oligohaline and upper mesohaline regions of Chesapeake Bay (authors' pers. obs.). Hooked mussels have a ribbed shell and are common in the mesohaline portion of Chesapeake Bay where they form clusters attached to hard substrate by byssal threads. The shells of $M$. arenaria (50 to $90 \mathrm{~mm}$ ) can be broken by forces ranging from 8 to $227 \mathrm{~N} ; 2$ to $680 \mathrm{~N}$ is required to break $R$. cuneata shells (up to $90 \mathrm{~mm}$ ), and 5 to $21 \mathrm{~N}$ to break $I$. recurvum shells (up to $50 \mathrm{~mm}$ ) (Blundon \& Kennedy 1982a).

Mollusks comprise one-third to one-half of the blue crab diet (Tagatz 1968, Laughlin 1982, Alexander 1986, Hines et al. 1990, Van Heukelem 1991). Blue crab predation is important in controlling soft clam populations and may be an important factor affecting other bivalve populations as well (Virnstein 1977. 1979). Blue crab predation on bivalves is strongly affected by prey size (Hughes \& Seed 1981, Eggleston 1990b, Linton 1990, Ebersole \& Kennedy 1994). Prey refuges such as density and burial depth affect blue crab predation on a variety of bivalve species, including the soft clam, in Chesapeake Bay (Blundon \& Kennedy 1982b, Lipcius \& Hines 1986, Eggleston 1990b). Laughlin (1982) concluded that blue crabs use whichever foods are available at any time; he called this high 'feeding adaptiveness'. This feeding behavior has also been called 'opportunistic'

We examined blue crab predation in light of optimal foraging theory, using Elner \& Hughes' (1978) energy maximization model to develop our experimental design. Optimal foraging theory is based on the premise that natural selection favors feeding behaviors that result in maximum fitness of the feeding animal (MacArthur \& Pianka 1966, Charnov 1976, Pyke et al. 1977). The theory provides a useful framework for developing testable hypotheses and designing feeding behavior experiments. If encounter rates are constant, energy maximization models based on optimal foraging theory predict that animals will select prey that provide maximum profitability, often measured in energy gained per unit of handling time $\left(\mathrm{J} \mathrm{s}{ }^{-1}\right)$ (Elner \& Hughes 1978, Juanes \& Hartwick 1990).

Elner \& Hughes' (1978) energy maximization model predicts that when predators encounter 2 prey types, they should select the more profitable prey rather than generalize on both types when $1 / r_{1}<\left(E_{1} / E_{2}\right)\left(T_{2}-T_{1}\right)$, where $r_{1}$ is the rate of encounter: $E_{1}$, the energy yield of prey type $1 ; E_{2}$, the energy yield of prey type $2 ; T_{1}$, the handling time of prey type $1_{\text {; }}$ and $T_{2}$, the handling time of prey type 2 . This equation does not consider energy costs involved with handling, nutritional requirements, or search time (Elner \& Hughes 1978).

Bivalve prey profitability curves are often compared to observed bivalve consumption by crabs to determine whether or not crabs choose 'optimally sized' prey (Elner \& Hughes 1978, Davidson 1986, Creswell \& McLay 1990). Attempts are generally made to keep encounter rates approximately equal by using equal ratios of bivalve numbers, weights, or surface areas, and then varying these ratios from one experiment to another.

Our study investigated the usefulness of Laughlin's (1982) opportunistic forager concept versus prey profitability curves based on Elner \& Hughes' (1978) energy maximization model as predictors of blue crab preferences. In 3 separate sets of experiments, we examined prey consumption and prey preference between 2 species of different profitabilities: 'Design 1', between Mya arenaria and Rangia cuneata; 'Design 2', between $M$. arenaria and Ischadium recurvum; and 'Design 3', between $R$. cuneata and $I$. recurvum. Prey profitability was determined by dividing net energy intake by handling time $\left(\mathrm{J} \mathrm{s}^{-1}\right)$ for each of the 3 prey species. These experiments also examined the effects of 3 additional factors on prey preference and prey consumption: prey location, prey refuge availability, and prey density (see Fig. 1). For the purposes of this article, prey preference is defined as the difference between the proportion of prey 1 and prey 2 eaten; consumption is defined as the proportion of prey 1 , prey 2 , or total prey eaten.

To examine the effect of location on prey preference and consumption, we used 3 different prey location arrangements. They were (1) 'near' to the point of introduction of the blue crab into an aquarium, (2) 'distant' from the point of introduction, or (3) 'mixed', i.e. half of each prey type were located 'near' and half were 'distant'.

Burial for infaunal prey and clustering for byssate prey are known to provide refuges from crab predation (Blundon \& Kennedy 1982b, Lin 1991). To examine how the availability of prey refuges affected prey preference and consumption, we used 2 refuge availability regimes: prey refuges were either (1) 'unavailable' (shallow sand and detached mussels) or (2) 'available' (deep sand and byssally attached mussels in clusters).

Prey density is known to affect prey consumption measured in absolute numbers, but not prey consumption measured as the proportion of prey eaten (Lipcius \& Hines 1986, Sponaugle \& Lawton 1990, Mansour \& Lipcius 1991). To examine the effects of prey density on prey preference and consumption, 2 density regimes were used: prey density was (1) 'low' (biomass approximately equivalent to 4 clams per aquarium) or (2) 'high' (approximately equivalent to 16 clams per 
aquarium). We found that prey profitability, refuge availability, and prey location influenced prey preference by blue crabs.

\section{METHODS}

We collected Callinectes sapidus from the Choptank River near Horn Point Environmental Laboratory and from a tributary to the Little Choptank River with crab pots, trot lines, and dip nets. To reduce variation, we used only male intermolt crabs that were intact and fed actively. We used blue crabs of 130 to $160 \mathrm{~mm}$ carapace width; this size class represents the largest of Laughlin's (1982) 3 trophic groups and overlaps the size class (130 to $140 \mathrm{~mm}$ carapace width) used by Lipcius \& Hines (1986) in functional response studies. Lipcius \& Hines (1986) considered this range to be a representative dominant size class in Chesapeake Bay. In all experiments, crabs were starved for $48 \mathrm{~h}$ before each trial to standardize hunger levels (see below for details). Each crab was used only once.

The infaunal species of prey (Mya arenaria and Rangia cuneata) are commonly found in sandy or sandy/ mud sediment in the Choptank River whereas the epifaunal Ischadium recurvum lives on hard substrate such as rocks, pilings, or oyster shells in the same general area as the infaunal species. We collected $R$. cuneata and some I. recurvum by hand. Other $I$. recurvum were collected with an oyster dredge. We obtained $M$ arenaria from a local seafood distributor or from material collected by personnel of the Cooperative Biological Laboratory in Oxford, Maryland. As in Lipcius \& Hines' (1986) functional response experiments, only intact adult $M$. arenaria that exhibited vigorous siphon withdrawal responses were used, as well as $R$. cuneata and $I$. recurvum that closed upon handling. We used 50 to $75 \mathrm{~mm}$ long M. arenaria, 30 to $45 \mathrm{~mm} \mathrm{R}$. cuneata, and 15 to $60 \mathrm{~mm} \mathrm{I}$. recurvum. We distributed small, medium, and large I. recurvum haphazardly among treatments, using this species' weight to balance the weights of the 2 or 8 individuals of the other 2 bivalve species in preference experiments (see below).

Prey profitability. Prey profitability was averaged for each prey species across the range of sizes used in experiments. This action considered neither search time nor energetic costs of various handling activities.

In a separate study (Ebersole \& Kennedy 1994), we determined handling times and profitabilities for Rangia cuneata by use of the procedures outlined below for the other 2 bivalve species. We froze, freeze-dried, and ground tissue from 57 to $68 \mathrm{~mm}$ Mya arenaria and 18 to $55 \mathrm{~mm}$ Ischadium recurvum and estimated the energy content (calories $\mathrm{g}^{-1}$ ) for 9 samples of tissue for each bivalve species. We estimated energy content with an oxygen bomb calorimeter (Parr Instrument Co. 1960) when enough tissue was available (at least $1 \mathrm{~g}$ dry wt), and we used a microbomb calorimeter (Phillipson 1964) when tissue samples weighed less than $1 \mathrm{~g}$ dry wt. Calories were converted to joules to be consistent with recent literature on crustacean feeding behavior (Creswell \& McLay 1990, Juanes \& Hartwick 1990).

Handling times were measured with a stopwatch to the nearest second for 9 hooked mussels ranging from 16 to $59 \mathrm{~mm}$ and for 3 soft clams $(54,56,63 \mathrm{~mm})$ by direct observation of crabs placed singly in small glass aquaria filled with filtered estuarine water from the Choptank River (only 3 soft clams were used because our data corresponded closely to data in Linton 1990). There was no sand in the aquaria so handling times did not include digging time. Handling time began when a $c r a b$ first attempted to grasp or lift a prey, ended when the crab abandoned the prey's open shell for $60 \mathrm{~s}$ or longer, and included breaking and eating times, which were defined as follows (adapted from Elner \& Hughes 1978):

Breaking time: time from the crab's initial active encounter with the prey (e.g. manipulation of the prey with the chelae), through the period of shell crushing, to the first bite of exposed flesh.

Eating time: time from the first bite of exposed flesh to the abandonment of the open shell, including time spent handling and rebreaking the shell to extract flesh. An open shell was considered abandoned if the crab dropped it and did not touch it for at least $60 \mathrm{~s}$.

We used correlation analysis to compare dry weight, energy content, and handling time with clam length (Snedecor \& Cochran 1980). Profitability was calculated for each size class as energy content (calories $\mathrm{g}^{-1}$ ) $x$ dry weight $\left(\mathrm{g} \mathrm{clam}^{-1}\right)$ per unit handling time ( $\mathrm{slam}^{-1}$ ). If a significant correlation existed $(p<0.05)$, then the response variable (i.e. dry weight, energy content, or handling time) was regressed against clam length and the predicted value for the $10 \mathrm{~mm}$ size class midpoint (i.e. the predicted value corresponding to $15 \mathrm{~mm}, 25 \mathrm{~mm}$, etc.) was used to calculate profitability. If no significant correlation existed, the mean value for each $10 \mathrm{~mm}$ size class was used to calculate profitability. Because of the narrow range of sizes of Mya arenaria used, they were grouped as 1 size class, and the mean value was used. Ischadium recurvum were

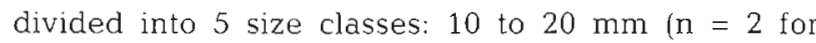
handling times; $\mathrm{n}=1$ for energy content), 20 to $30 \mathrm{~mm}$ $(\mathrm{n}=2,2), 30$ to $40 \mathrm{~mm}(\mathrm{n}=2,2), 40$ to $50 \mathrm{~mm}(\mathrm{n}=2,2)$, and 50 to $60 \mathrm{~mm}(\mathrm{n}=1,2)$, where $\mathrm{n}$ is the number of mussels in each size class. The profitabilities for each size class of $I$. recurvum were calculated separately 
and then averaged to find the mean profitability for the species. The methods for calculating profitability for Rangia cuneata are described in Ebersole \& Kennedy (1994).

Prey preference and consumption. The experimental design is displayed graphically in Fig. 1. In total, 90 blue crabs were used.

Design 1, Mya arenaria versus Rangia cuneata (n = 36 blue crabs in 12 treatments): For experiments at
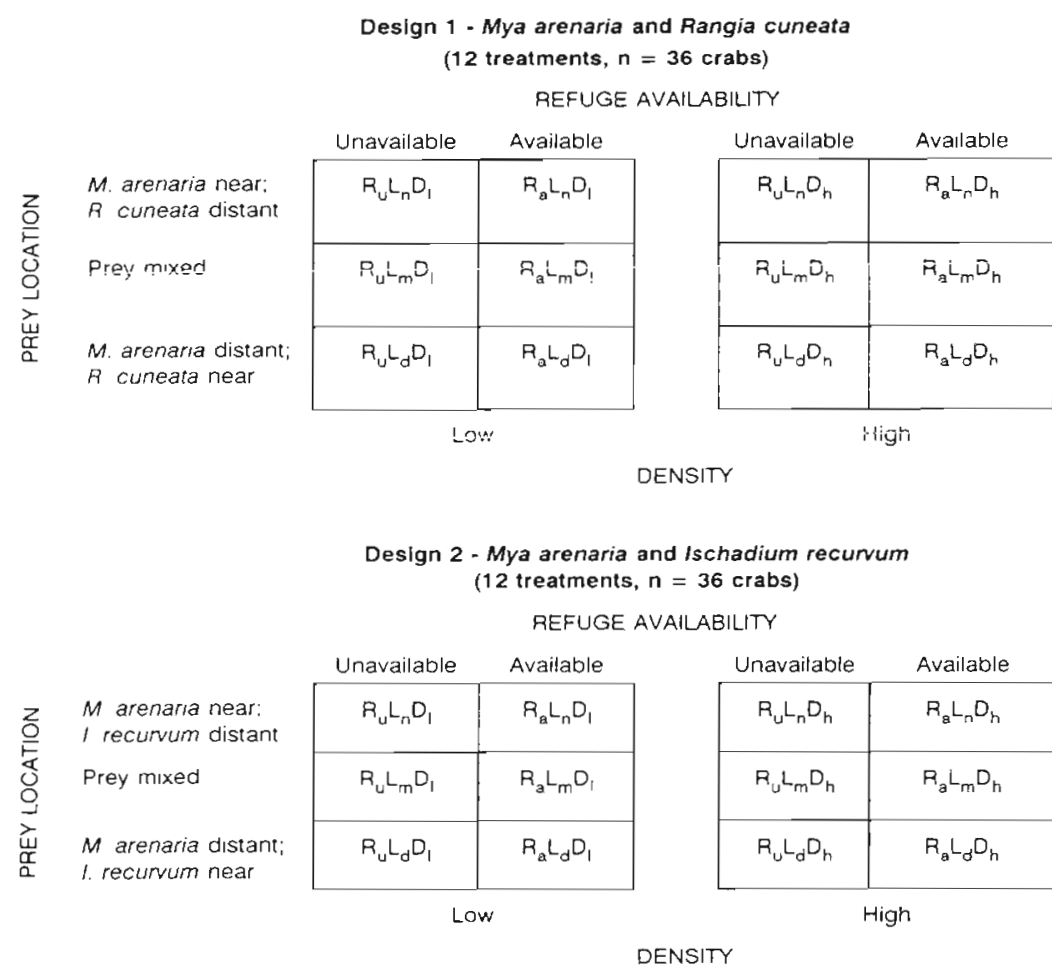

Design 3 - Rangia cuneata and /schadium recurvum (6 treatments, $n=18$ crabs)

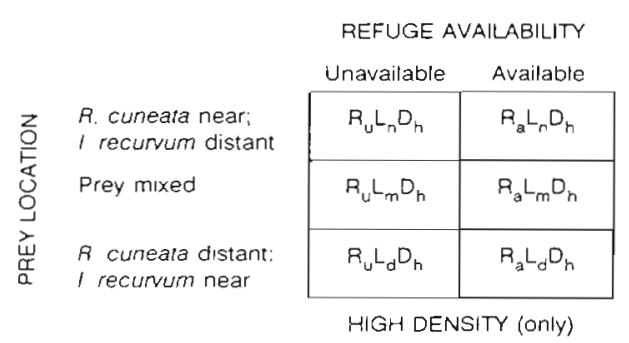

Fig. 1. Schematic diagram of the factorial design of the experiments. Designs 1 and 2 were each conducted as a $2 \times 3 \times 2$ factorial: 2 levels of prey refuge availability (shallow sand/detached mussels and deep sand/clustered mussels); 3 levels of prey location (prey 1 near, prey 2 near, and mixed); and 2 levels of density (low and high). Density was not considered in Design 3, which was conducted as a $2 \times 3$ factorial. The following symbols were used to represent each treatment: Refuge availability $(R)$ : unavailable $\left(R_{u}\right)$, available $\left(R_{a}\right)$; Prey location (L): prey 1 near and prey 2 distant $\left(L_{n}\right)$, mixed $\left(L_{m}\right)$, prey 1 distant and prey 2 near $\left(L_{d}\right)$; Prey density $(D)$ : low $\left(D_{1}\right)$, high $\left(D_{h}\right)$ high prey densities, we placed $3 \mathrm{~cm}$ of sand in each of six $220 \mathrm{l}(120 \times 30 \times 50 \mathrm{~cm})$ glass aquaria to avoid the effects of a possible depth refuge for the burrowing clams. The aquaria were then filled with running

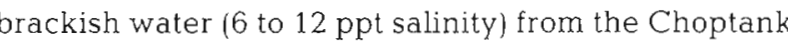
River and divided into 7 sections by plastic grate material $(1.25 \mathrm{~cm}$ mesh) used as baffles. One plastic grate separated Section A from Section B of the aquarium and 5 additional grates were located in Section $C_{\text {, sep- }}$ arating Section B from Section D (Fig. 2 ). We cut 1 or 2 rectangular holes $(4 \times$ $10 \mathrm{~cm}$ ) at alternate side edges of each plastic grate. We used 2 holes for shallow sand treatments because the water column was deeper in those treatments; for deep sand treatments, we only provided 1 rectangular hole. Each hole was large enough for a crab to pass through. The plastic grate baffles slowed the crab's movement from one end of the aquarium to the other and simulated distance. (The shortest time recorded for a crab to travel from Section A to Section D was $26 \mathrm{~min}$, but most crabs traveled the distance in more than $3 \mathrm{~h}$ and less than $48 \mathrm{~h}$. Travel time varied greatly because crabs rarely traveled directly from Section A to Section D, but usually traveled repeatedly back and forth between adjacent sections.)

To begin an experiment, we placed a crab into Section A and allowed it to travel freely and acclimate to the aquarium for $24 \mathrm{~h}$. We then confined the crab for an additional $24 \mathrm{~h}$ to Section A with a plastic grate that had no rectangular hole cut in it. At the same time, we buried 8 medium-sized healthy Mya arenaria (15 to $40 \mathrm{~g}$ and 50 to $75 \mathrm{~mm}$ each) in Section B of the aquarium ('near') and 8 medium-sized healthy Rangia cuneata (15 to $40 \mathrm{~g}$ and 30 to $45 \mathrm{~mm}$ each) in Section D ('distant') and allowed them to adjust to the conditions for $24 \mathrm{~h}$. Our design allowed the crab to be starved during the $24 \mathrm{~h}$ of crab acclimation and the additional $24 \mathrm{~h}$ of prey acclimation, for a total of $48 \mathrm{~h}$. We then allowed the $c r a b$ to travel through the aquarium and eat at will for $48 \mathrm{~h}$. Prey were not replaced. At the end of each trial, we determined the number of prey eaten by counting surviving clams and the 
Fig. 2. Diagram of experimental aquarium, showing placement of plastic grating in shallow sand treatment. A: area where crab was introduced; $B$ : location of prey $1 ; C$ : area available for crab to travel between prey; $D$ : location of prey 2. Arrow indicates incoming Choptank River water

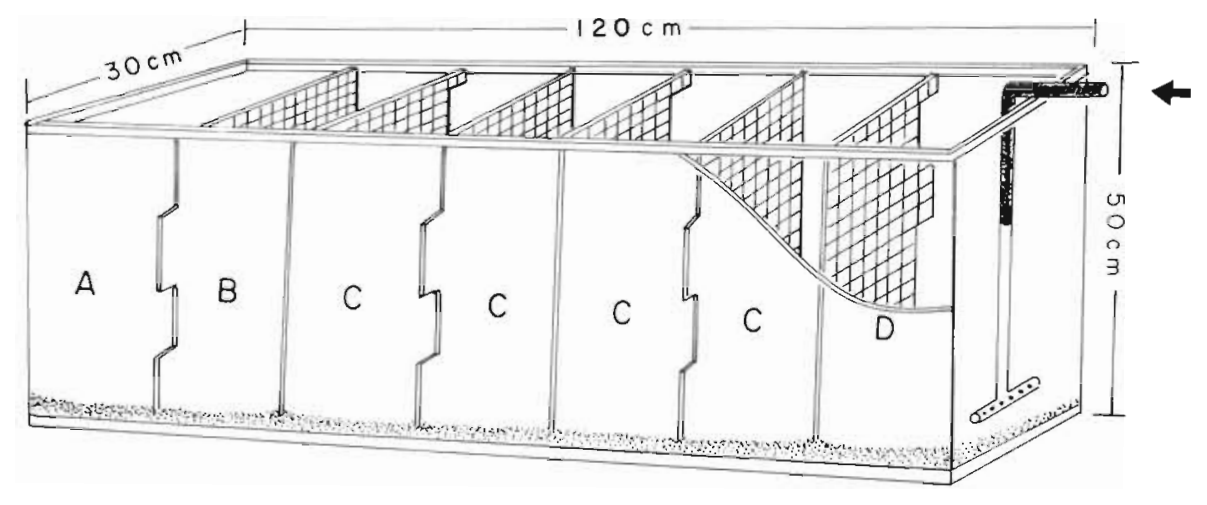

umbos of eaten clams. This set of experiments (a single treatment) used a total of 3 blue crabs in 3 separate replicates.

The same procedure was followed in a second treatment with 8 Mya arenaria in Section D as 'distant' prey and 8 Rangia cuneata in Section B as 'near' prey, again with 3 blue crabs. Finally, the experiment was conducted in a third treatment with $4 M$. arenaria and $4 R$. cuneata together in Section $B$ and another set of 4 each in Section D, with 3 more blue crabs. Thus there were 3 prey location treatments, with a total of 9 blue crabs tested.

Three additional treatments at low prey densities were conducted as above with 9 additional blue crabs but with a total of only 2 Mya arenaria and 2 Rangia cuneata in each aquarium. Thus, for the 6 treatments described, each $220 \mathrm{l}$ tank contained a total of 16 clams in high density experiments or 4 clams in low density experiments.

To determine if burial depth provided a refuge, we conducted 6 more treatments as described above (at both high and low densities), but in $20 \mathrm{~cm}$ of sand. We buried Mya arenaria at 10 to $15 \mathrm{~cm}$ and Rangia cuneata just under the surface. The clams had $24 \mathrm{~h}$ to acclimate to the aquarium and to adjust their burial depths. This depth more closely resembles conditions in the field than the shallow sand treatments (Blundon \& Kennedy 1982b, Hines \& Comtois 1985). Prey arrangements and sand depths were randomly assigned to aquaria within blocks of time.

Overall, a total of 12 treatments ( 3 blue crabs each) were conducted in Design 1 (Fig. 1).

Design 2, Mya arenaria versus Ischadium recurvum ( $n=36$ blue crabs in 12 treatments): All trials were repeated at high and low densities as in Design 1 , but we replaced the infaunal Rangia cuneata with the epifaunal Ischadium recurvum (Fig. 1). We used clustered versus detached I. recurvum to determine if clustering provided a refuge from crab predation. Ischadium recurvum were provided in equal weight (but not necessarily equal numbers) to the weight of 8 (high density) or 2 (low density) Mya arenaria. In deep sand trials, the mussels used were attached byssally to oyster shells or stones placed on the sand surface, whereas they were scattered on the sand surface as detached, separate individuals during shallow trials.

Design 3, Rangia cuneata versus Ischadium recurvum ( $\mathrm{n}=18$ blue crabs in 6 treatments): Experiments were repeated as in Design 2, except that Rangia cuneata replaced Mya arenaria. Because the results of Designs 1 and 2 showed that the density differences had little effect on prey species preference by blue crabs in this experimental setting, Design 3 experiments were conducted at high densities only (Fig. 1).

Statistical analyses. We conducted analyses of variance on 4 response variables: (1) the consumption of prey 1 (the proportion of prey 1 eaten), (2) the consumption of prey 2 (the proportion of prey 2 eaten), (3) the preference between prey 1 and prey 2 (the difference between the proportion of prey 1 and prey 2 eaten), and (4) the consumption of total prey (the proportion of total prey eaten). Designs 1 and 2 were each conducted as a $2 \times 3 \times 2$ factorial (Fig. 1): 2 levels of prey refuge availability (shallow sand/detached mus sels and deep sand/clustered mussels); 3 levels of prey location (prey 1 near, prey 2 near, and mixed); and 2 levels of density (low and high). Designs 1 and 2 had a total of 12 treatments, and 36 crabs were used in each design. Because only 6 aquaria were available at one time, low and high density treatments were conducted in different weeks. Results were analyzed as a splitplot in time where density was the split-plot factor. Density was not considered in Design 3 , which was conducted as a $2 \times 3$ factorial (Fig. 1): 2 levels of prey refuge availability and 3 levels of prey location. Design 3 had a total of 6 treatments and 18 crabs. The results of each design were analyzed separately and were not compared statistically to the results of the other designs. The same crab was never used more than once. 
To determine differences among treatments, we conducted means comparisons on pre-planned contrasts. Means reported are corrected for any unequal replication due to missing data (1 crab molted in Design 1 , causing 1 missing data point). Corrected means less than zero are reported as zero. Differences are reported as significant if $\alpha \leq 0.05$. Sample sizes (n) reported are total numbers of crabs used in each design. A Levene's test for homogeneity of variance (Milliken \& Johnson 1984) indicated that variances of the differences were homogeneous, so there was no need for a transformation.

A crab preference for one prey species over another was reported under a given treatment if the $t$-test performed on the difference showed that the difference was not equal to zero at $\alpha \leq 0.05$. A difference in prey preference between 2 treatments was reported if the $t$-test performed on the difference showed that the difference under $\hat{1}$ treatment was signiticantly different from the difference under the other treatment at $\alpha \leq$ 0.05 .

Due to the factorial nature of the design, we were able to takc advantage of hiduen replications when appropriate. If a factor is not identified on a graph or in the text, values for that factor have been combined across relevant treatments. For example, in Fig. 4, results are averaged across all 3 prey location arrangements and both densities (i.e. across 6 treatments; thus each bar represents the mean value for 18 crabs). We have reported just some of the data in graphical form because of space limitations.

\section{RESULTS AND DISCUSSION}

\section{Prey profitability}

In the size ranges examined, Mya arenaria (50 to $70 \mathrm{~mm}$ long) had a much greater prey profitability (44 J $\mathrm{s}^{-1}$ ) than Rangia cuneata (30 to $40 \mathrm{~mm}$ long; $0.07 \mathrm{~J} \mathrm{~s}^{-1}$; Ebersole \& Kennedy 1994), with the average profitability of Ischadium recurvum (10 to $60 \mathrm{~mm}$ long; $6.1 \mathrm{~J} \mathrm{~s}^{-1}$ ) falling between the other 2 species.

For Mya arenaria, neither energy content, dry weight, nor handling time was significantly correlated with clam length within the narrow range of clam sizes used ( 57 to $68 \mathrm{~mm}$ ) (Pearson correlation coefficients, $r=-0.39, p=0.30$ for energy content; $r=0.57$, $p=0.11$ for dry weight; and $r=0.39, p=0.74$ for handling time). The mean energy content was $20400 \mathrm{~J}$ $\mathrm{g}^{-1}$ and the mean dry weight was $2.33 \mathrm{~g} \mathrm{clam}^{-1}$. The mean handling time was $1070 \mathrm{~s}$, similar to Linton's (1990) handling time (approximately $1000 \mathrm{~s}$ ) for 115 to $185 \mathrm{~mm}$ blue crabs feeding on 65 to $90 \mathrm{~mm} \mathrm{M}$. arenaria.
For Ischadium recurvum, energy content was not significantly correlated with mussel length (Pearson correlation coefficient, $r=-0.92, p=0.08$ ), but dry weight and handling time correlated significantly with mussel length (Pearson correlation coefficient, $r=0.89$, $p=0.0014$ for dry weight; $r=0.82, p=0.0073$ for handling time). Mean energy content was $20700 \mathrm{~J} \mathrm{~g}^{-1}$. The regression equation for predicted dry weight was:

$$
\text { Dry weight }(g)=0.007 \text { Length }(\mathrm{mm})-0.074
$$$$
\left(\mathrm{R}^{2}=0.90, \mathrm{n}=9\right)
$$

The regression equation for predicted handling time was:

$$
\begin{gathered}
\log _{e} \text { Handling time }(h)=2.22\left(\log _{e} \text { Length }\right)-5.66 \\
\left(R^{2}=0.67, n=9\right)
\end{gathered}
$$

\section{Prey preference and consumption}

\section{Design 1, Mya arenaria versus Rangia cuneata}

In Design 1, prey profitability had the greatest effect on feeding behavior, followed by prey refuge availability, and prey location.

Prey profitability. In both shallow and deep sand (i.e. averaged across all prey locations and both prey densities), crabs ate significantly more of the highly profitable Mya arenaria than the much less profitable Rangia cuneata, indicating a strong preference for the soft clams $(59 \% M$. arenaria vs $2 \% R$. cuneata in shallow sand, $p=0.01 ; 26 \% M$. arenaria vs $6 \% R$. cuneata in deep sand, $p=0.0001$ ). Shell remains from eaten $M$. arenaria were often broken into many pieces, whereas shell remains from eaten $R$. cuneata were usually intact, except that the edges were chipped and the valves were separated. Chipped edges and scratched periostracum of many unopened $R$. cuneata indicated that crabs had handled and rejected these prey. Thus prey profitability appeared to be the most important factor affecting prey preference.

Prey refuge availability. Sand depth significantly affected preference. Although blue crabs preferred Mya arenaria over Rangia cuneata at both sand depths, there was a stronger preference for $M$. arenaria in shallow sand than in deep sand ( $p=0.005)$. This may be because $M$. arenaria were able to bury deep in the sediment, whereas the $R$. cuneata could not, and deep burial depth has been shown to provide a partial prey refuge (Blundon \& Kennedy 1982b, Lipcius \& Hines 1986). Although consumption of $M$. arenaria was significantly higher in shallow sand than in deep sand $(p=0.005)$, sand depth did not significantly affect blue crab consumption of $R$. cuneata. 
Prey location. Prey location (near, distant) significantly affected preference only when the refuge of deep burial was removed, i.e. in shallow sand.

In shallow sand a significantly greater preference existed for Mya arenaria over Rangia cuneata when $M$. arenaria were near than when they were distant $(\mathrm{p}=$ 0.04) (Fig. 3). Crabs ate significantly more $M$. arenaria than $R$. cuneata at each prey location in shallow sand $(\mathrm{p}=0.03)$. When $M$. arenaria were near, crabs ate an average of $73 \%$ of the $M$. arenaria and none of the $R$. cuneata; when $M$. arenaria were distant, crabs ate $42 \%$ of the $M$. arenaria versus $10 \%$ of the $R$. cuneata (Fig. 3). In deep sand, however, prey location did not significantly affect prey preference, i.e. the difference between the proportion of $M$. arenaria and $R$. cuneata eaten did not vary significantly $(\mathrm{p}=0.2)$ regardless of which prey was encountered first (Fig. 3).

Prey density. Prey density did not affect prey preference in shallow or deep sand, but in deep sand prey density did affect consumption (Fig. 4). In shallow sand

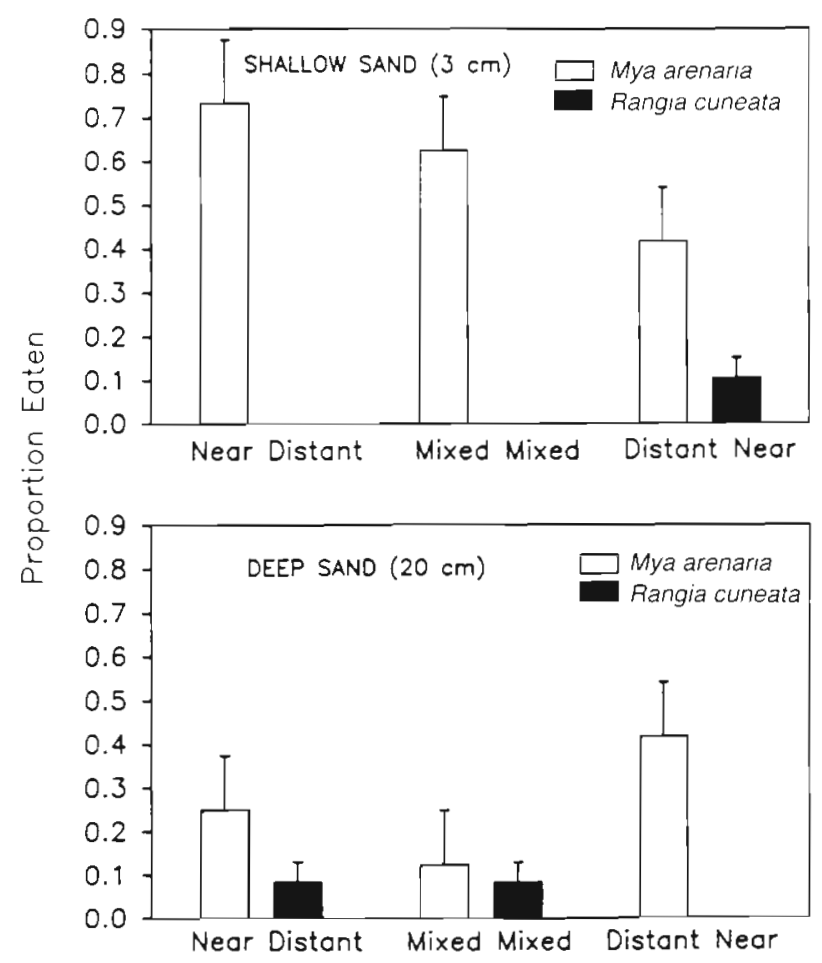

Fig. 3. Effect of prey location on consumption (mean proportion of clams consumed after $48 \mathrm{~h}$ ) of Mya arenaria and Rangia cuneata by Callinectes sapidus in shallow $(3 \mathrm{~cm})$ and deep $(20 \mathrm{~cm})$ sand. Each bar represents both prey densities (i.e. 2 treatments) combined. 'Near' indicates prey located in Section $B$, the section closest to the crab introduction site. 'Distant' indicates prey located in Section $D$, the section farthest from the crab introduction site. 'Mixed' denotes that equal numbers of $M$. arenaria and $R$. cuneata were in Sections $B$ and $\mathrm{D}$. (Error bar is $1 \mathrm{SE} ; \mathrm{n}=36$ crabs, i.e. $18 \mathrm{crabs}$ at each sand depth) treatments, the consumption of Mya arenaria at low prey density ( $54 \%$ ) did not differ significantly from the consumption at high prey density $(64 \%)$, nor did the consumption of Rangia cuneata differ significantly between low density (3.9\%) and high density (1.4\%) (Fig. 4). In deep sand, an average of $39 \%$ of $M$. arenaria were eaten at low density versus $14 \%$ at high density (no significant difference; $\mathrm{p}=0.10$ ), and $11 \%$ of $R$. cuneata were eaten at low density versus none at high density (significant difference; $p=0.05$ ) (Fig. 4). Crabs consumed a significantly higher proportion of total prey (both species of bivalves combined) at low density than at high density $(p=0.03)$.

\section{Design 2, Mya arenaria versus Ischadium recurvum}

Prey profitability. There was no significant difference between the consumption of Mya arenaria and Ischadium recurvum overall (i.e. averaged across all 12 treatments), so prey profitability was not an important factor affecting prey preference between these 2 species.

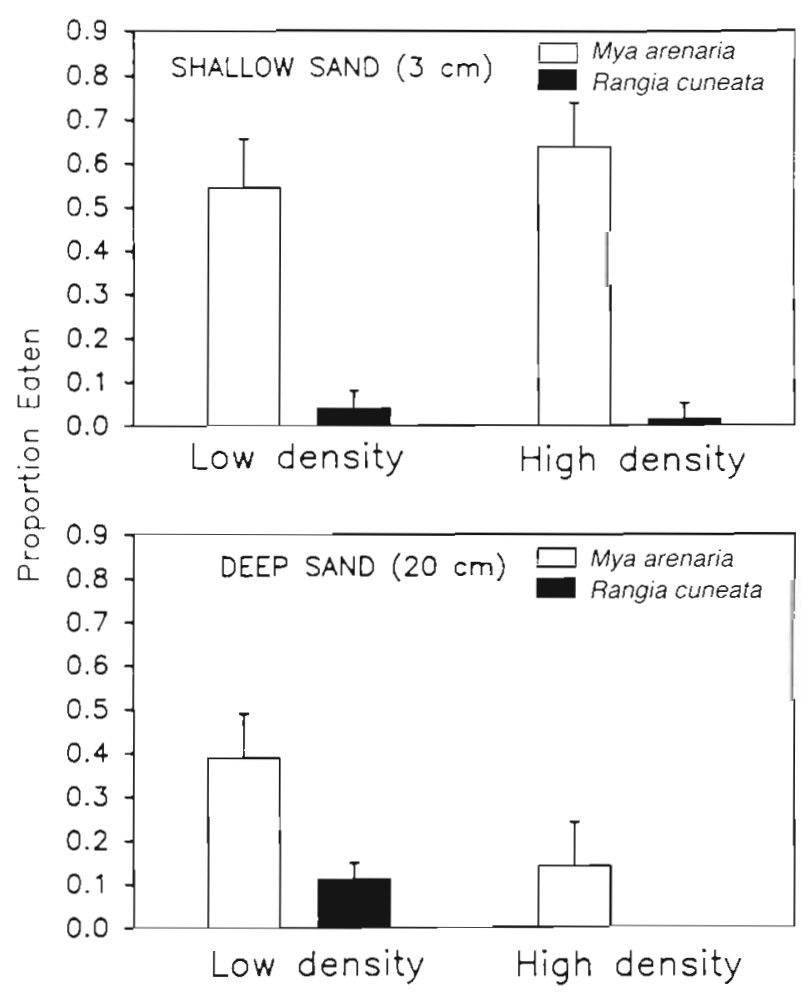

Fig. 4. Effect of clam density on consumption (mean proportion of clams consumed after 48 h) of Mya arenaria and Rangia cuneata by Callinectes sapidus in shallow $(3 \mathrm{~cm})$ and deep $(20 \mathrm{~cm})$ sand. Each bar represents all 3 prey location arrangements, i.e. 3 treatments, combined. Low density $=4$ clams aquarium $^{-1}$; high density $=16$ clams aquarium ${ }^{-1}$ (Error bar is $1 \mathrm{SE} ; \mathrm{n}=36$ crabs, i.e. 18 crabs at each sand depth) 


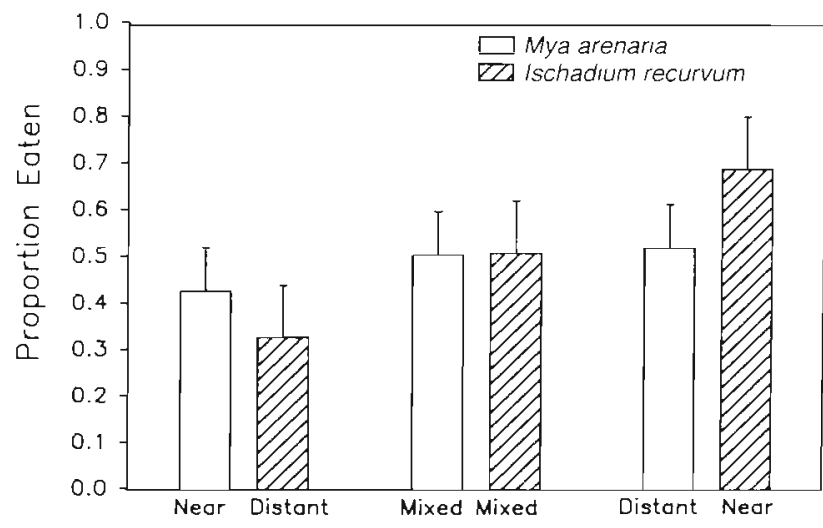

Fig. 5. Effect of prey location on consumption (mean proportion of prey consumed after $48 \mathrm{~h}$ ) of Mya arenaria and Ischadium recurvum by Callinectes sapidus. Each bar represents both refuge availabilities and both densities, i.e. 4 treatments combined. 'Near' and 'Distant' as in Fig. 3; 'Mixed' denotes that equal weights of $M$. arenaria and $I$ recurvum were in Sections B and D. (Error bar is $1 \mathrm{SE} ; \mathrm{n}=36 \mathrm{crabs}$ )

Prey refuge availability. Prey refuge availability affected consumption but not prefesence. The difference between the proportions of Mya arenaria and Ischadium recurvum eaten (i.e. preference) did not vary significantly between the deep sand/clustered mussels treatments and the shallow sand/detached mussels treatments. However, refuge availability did significantly affect consumption of $M$. arenaria (but not of $I$. recurvum). As in Design 1, crabs ate a significantly higher proportion $(p=0.004)$ of $M$. arenaria in shallow sand $(66 \%)$ than in deep sand $(32 \%)$. Crabs did not eat a significantly higher proportion of 1 . recurvum when detached $(59 \%)$ than when clustered and attached to a substrate $(44 \%)$.

At high densities, there was no significant difference between the consumption of Mya arenaria in shallow (33\%) versus deep (24\%) sand, but at low densities, significantly more $M$. arenaria were consumed in shallow sand $(100 \%)$ than in deep sand $(39 \% ; p=0.0007)$. Refuge availability (clustered versus detached) did not significantly affect consumption of Ischadium recurvum at high or low densities.

Prey location. Overall, prey location affected the consumption of Ischadium recurvum but not of Mya arenaria. A significantly higher proportion of $I$. recurvum was eaten when they were near than when they were distant ( $p=0.03$ ) (Fig. 5). In shallow sand, crabs preferred $M$. arenaria to detached $I$. recurvum when the $M$. arenaria were near $(p=0.05)$ but showed no preference when the $I$, recurvum were near. In deep sand, prey location did not affect blue crab preference (Fig. 6).

At high densities, prey location affected the consumption of Ischadium recurvum but not of Mya are- naria; significantly more 1 . recurvum were eaten if they were near $(55 \%)$ than if they were distant $(10 \% ; p=$ 0.05) (Fig. 7). When the I. recurvum were near prey and prey density was high, the crabs ate more $I$. recurvum $(55 \%)$ than $M$. arenaria $(22 \%)$, but this preference was not statistically significant $(p=0.06)$ (Fig. 7).

Prey density. As in Design 1, density did not affect prey preference but did affect prey consumption, in that crabs ate a higher proportion of each prey type at low density than at high density (Fig. 8). This difference was significant for Mya arenaria ( $p=0.001$ ) but not for Ischadium recurvum $(\mathrm{p}=0.07)$. Overall, there was no difference between the consumption of $M$. arenaria versus the consumption of $I$. recurvum at either density. A lower proportion of total prey (both bivalve species combined) was eaten at high density (Fig. 8). In shallow sand, crabs ate significantly more M. arenaria at low density $(100 \%)$ than at high density $(33 \%)$. In deep sand, there was no statistically sig-

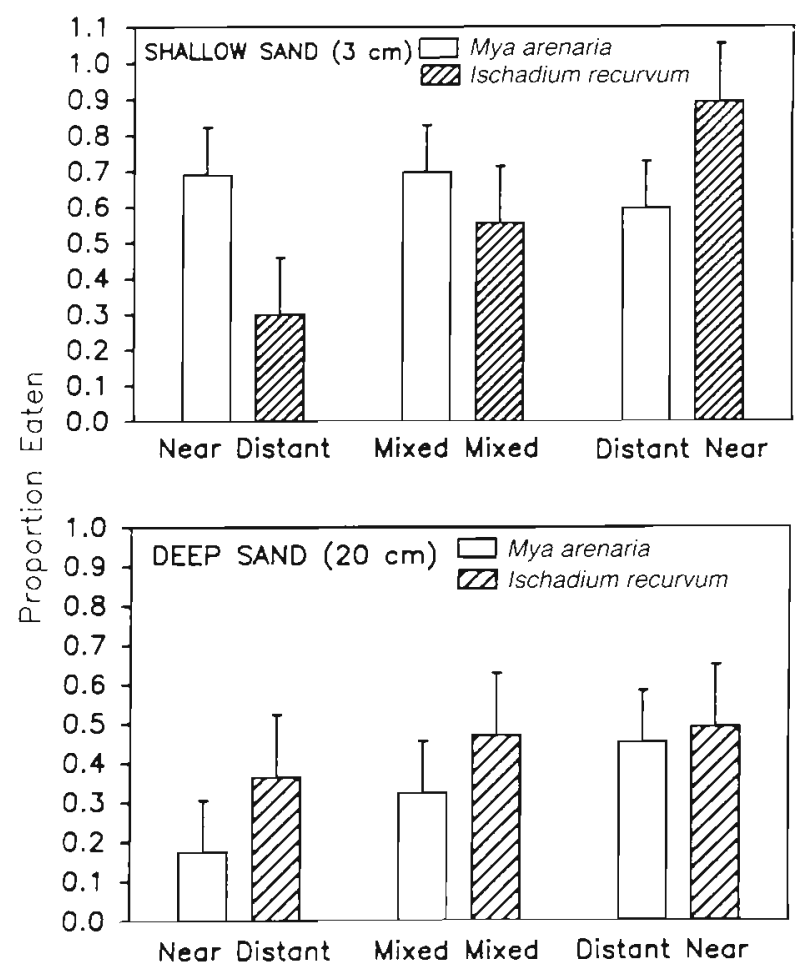

Fig. 6. Effect of prey location on consumption (mean proportion of bivalves consumed after $48 \mathrm{~h}$ ) of $M y a$ arenaria and $I s$ chadium recurvum by Callinectes sapidus in shallow $(3 \mathrm{~cm})$ and deep $(20 \mathrm{~cm})$ sand. Each bar represents both densities, i.e. 2 treatments, combined. 'Near', 'Distant' and 'Mixed' as in Fig. 5. I. recurvum individuals were placed directly on the surface of shallow sand or clustered on debris (rock or oyster shell) placed on the surface of deep sand, whereas $M$. arenaria were partially buried in shallow sand and completely buried in deep sand. (Error bar is $1 \mathrm{SE}_{i} \mathrm{n}=36$ crabs, i.e. 18 crabs at each sand depth) 


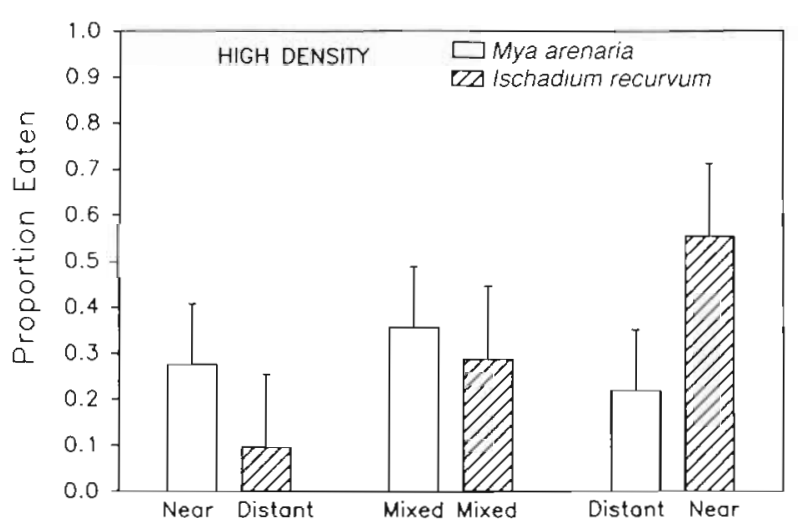

Fig. 7 Effect of prey location on consumption (mean proportion of bivalves consumed after 48 h) of Mya arenaria and Ischadium recurvum by Callinectes sapidus. Each bar represents both refuge regimes, i.e. 2 treatments, combined, at high prey density (weight equivalent of 16 soft clams aquarium-1). 'Near', 'Mixed' and 'Distant' as in Fig. 5. (Error bar is $1 \mathrm{SE}_{i} \mathrm{n}=18$ crabs)

nificant difference between the consumption of $M$. arenaria at low density (39\%) and at high density $(24 \%)$.

In Design 2, there was no overall preference for one species over the other, and this was not changed by any single factor. This result contrasts with what would be expected from the differing profitabilities of the 2 prey. As in Design 1, prey location was the determining factor only when the prey refuges (burial and clustering) were 'unavailable'.

\section{Design 3, Rangia cuneata versus Ischadium recurvum}

Prey profitability and refuge availability. In deep sand, there was no significant difference between the consumption of Rangia cuneata and the consumption of clustered Ischadium recurvum. In shallow sand, however, crabs ate significantly more detached $I$. recurvum $(71 \%)$ than $R$. cuneata $(27 \% ; \mathrm{p}=0.03)$. In Design 3, the effects of removing prey refuges were less pronounced than in Designs 1 and 2. This may be explained because no deep-burying prey were used. Also, a lower sample number $(n=18)$ may have made this design less statistically powerful than the others.

Prey location. Prey location significantly affected prey preference. Overall, significantly more Ischadium recurvum $(83 \%)$ than Rangia cuneata $(26 \%)$ were eaten when $I$. recurvum were near prey $(\mathrm{p}=$ 0.02) (Fig. 9). There was no significant difference between the proportion of $I$. recurvum ( $33 \%$ ) and $R$. cuneata $(41 \%)$ eaten when $R$. cuneata were the near prey.

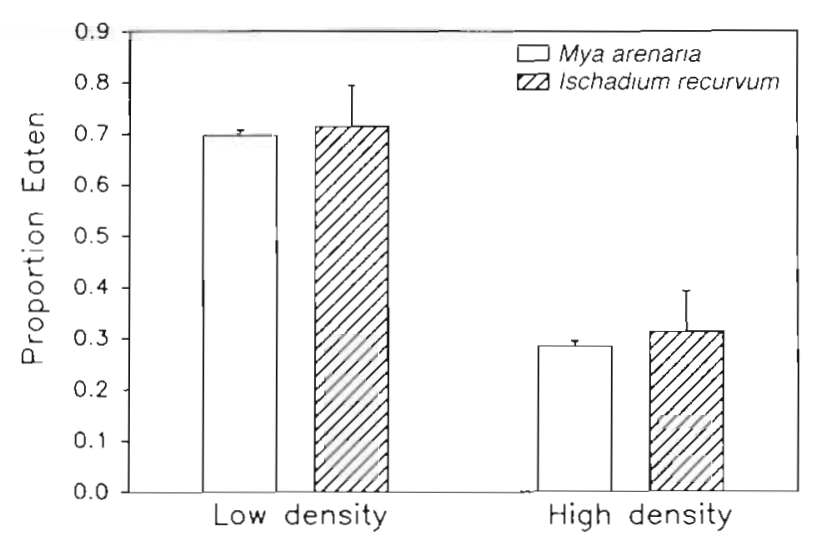

Fig. 8. Effect of prey density on consumption (mean proportion of prey consumed after $48 \mathrm{~h}$ ) of Mya arenaria and Ischadium recurvum by Callinectes sapidus. Each bar represents all 3 prey location arrangements and both refuge availability regimes, i.e. 6 treatments, combined. Low density is weight equivalent to 4 soft clams aquarium ${ }^{-1}$; high density is weight equivalent to 16 soft clams aquarium ${ }^{-1}$ (Error bar is $1 \mathrm{SE}_{;} n=$ 36 crabs, i.e. 18 crabs per density type)

\section{CONCLUSIONS}

Profitability curves based on the energy maximization model of Elner \& Hughes (1978) predicted that crabs should select Mya arenaria over Rangia cuneata, M. arenaria over Ischadium recurvum, and I. recurvum over $R$. cuneata. This model was a good predictor of blue crab prey preferences between bivalve prey with extremely different energy profitabilities (i.e. $M$. arenaria vs $R$. cuneata). When these profitability differences were not as great (i.e. $M$. arenaria vs I. recurvum

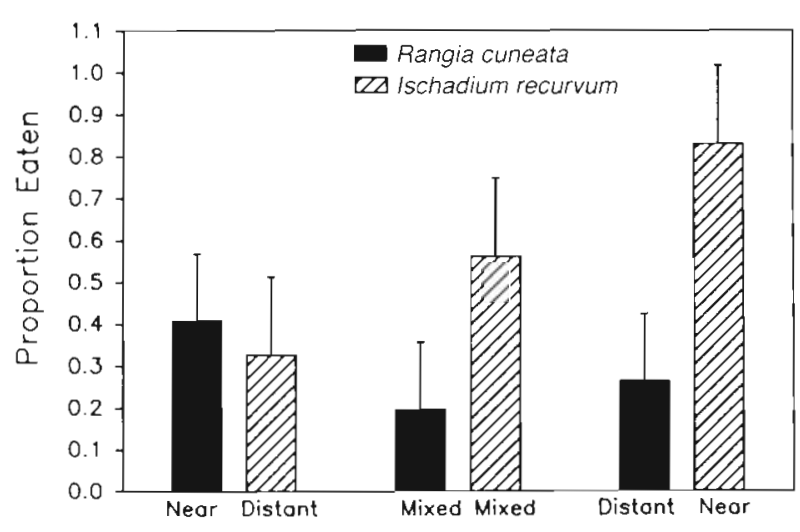

Fig. 9. Effect of prey location on consumption (mean proportion of bivalves consumed after 48 h) of Rangia cuneata and Ischadium recurvum by Callinectes sapidus. Each bar represents both refuge availability regimes, i.e. 2 treatments, combined. 'Near', 'Mixed' and 'Distant' as in Fig. 5. Individual $l$. recurvum were placed directly on the surface of shallow sand or clustered on debris (rock or oyster shell) placed on the surface of deep sand, whereas $R$. cuneata were partially buried in shallow sand and completely buried in deep sand. (Error bar is $1 \mathrm{SE}_{;} \mathrm{n}=18$ crabs) 
and $I$. recurvum vs $R$. cuneata), the simplified model did not predict well, and prey refuge availability (burial or clustering), prey location, and prey densities became relatively more important factors influencing feeding behavior.

Blue crabs always preferred the highly profitable Mya arenaria to Rangia cuneata regardless of sand depth or prey location. This supports Virnstein's (1979) designation of $M$. arenaria as 'favored' food of blue crabs. The blue crab's strong preference for mediumsized $M$. arenaria over medium-sized $R$. cuneata can be explained by the fact that the soft clam was handled quickly whereas the hard-shelled Atlantic rangia clam required much longer handling times (Ebersole \& Kennedy 1994). There was no such general preference for $M$. arenaria over Ischadium recurvum, and $I$. recurvum was significantly preferred over $R$. cuneata only in shallow sand/detached mussel treatments or when mussels were near prey. In these cases, the profitability differences were less pronounced, and other factors played a major role in determining the crab's preference. Our results indicate that unless profitabilities are extremely different, simple profitability curves are not sufficient to predict the preferences of blue crabs for bivalves, and perhaps for other prey types.

In terms of prey refuges, sand depth and clustering reduced prey consumption. Our results support previous work by Blundon \& Kennedy (1982b) that burial depth provides a partial refuge for Mya arenaria. The blue crab's preference for the highly profitable prey, $M$. arenaria, over Rangia cuneata was significantly greater in shallow sand than in deep sand, indicating that burial provides a greater refuge for the deep-burying soft clams than for the shallow-burying Atlantic rangia clams. Depth provided a greater refuge for $M$. arenaria than clustering provided for Ischadium recurvum. In turn, clustering provided a greater refuge for $I$. recurvum than deep sand provided for $R$. cuneata.

In terms of prey location, crabs tended to eat more near than distant prey in the absence of a depth refuge, i.e. in shallow sand. For infaunal prey in deep sand, however, there was no clear tendency for crabs to eat more near than distant prey. Laughlin's (1982) statement that 'all crabs utilize whatever food items are locally available at any time' implies that blue crab prey selection is based solely on horizontal distance to prey or travel time. This was not the case in our study. Blue crabs rejected prey with very low profitability (Rangia cuneata) and continued to search for prey with higher profitability (Mya arenaria). Experimenters must consider both search and handling times, and factors that affect these times. Prey refuges (such as burial depth, clustering, and shell strength) can increase search times, decrease encounter rates, and increase handling times.
In terms of prey density, low density did not provide a refuge for Mya arenaria, even in deep sand. Similarly, low density does not provide a refuge for the hard clam Mercenaria mercenaria from predation by the brachyuran crab Ovalipes ocellatus in sand (Sponaugle \& Lawton 1990) nor for the bivalve Paphies ventricosa from predation by the paddle crab Ovalipes catharus (Haddon et al. 1987). Eggleston (1990a) found that the proportion of oysters eaten by blue crabs was greatest at intermediate densities of 10 to 20 oysters per $72 \mathrm{l}$ aquarium. In contrast to these published observations and our data on $M$. arenaria, Lipcius \& Hines (1986) found that low density did provide a refuge for $M$. arenaria from blue crab predation. In their low density treatments, 2 prey items were spread randomly throughout the aquarium and crabs were allowed to travel freely through the tank. In our study, clams were concentrated in 2 prey patches separated by baffles and low density treatments contained at least 4 prey items per aquarium. The difference in prey location arrangements may explain our different results.

At high prey densities crabs ate more Ischadium recurvum than Mya arenaria when I. recurvum were the near prey, but there was no difference between the proportions of $I$. recurvum and $M$. arenaria eaten at low densities. A possible explanation of these data involves appetite satiation. The crabs may have remained hungry after eating all of the mussels provided in low density experiments, thus continuing to search for, open, and eat additional food. However, in the high density experiments, their hunger may have been reduced after eating most or all of the prey in the near section, thus slowing feeding activity.

Laughlin (1982) showed that blue crabs eat a large amount of Rangia cuneata in the Gulf of Mexico, a region where Mya arenaria does not occur. In our experiments, consumption of one prey varied depending on what other prey was present, i.e. the presence of one prey affected the mortality of the other prey. This suggests that the introduction of new species or the expansion of a prey population's range could affect both blue crab feeding behavior and existing prey populations in the area. Useful future experiments could be conducted in the field to investigate whether the presence or absence of high profitability prey affects blue crab predation on a low profitability prey. The ranges of $M$. arenaria and $R$. cuneata overlap in the Chesapeake Bay, so future research could investigate more complex predictive or explanatory foraging models that consider prey refuges, prey location, and prey density as well as prey profitability. These more complex models should be tested in the field as well as in the laboratory. Caution should be used to avoid experimental artifacts. Our results showed, for example, that blue crab consumption of the deep-burrowing soft 
clam $M$. arenaria was completely different in shallow sand than in deep sand, the latter being a setting that more closely resembles the clam's natural habitat.

Acknowledgements. We thank A. Barse, R. Clark, C. Kennedy, D. Kennedy, C. Wigand and L. Wootton for their assistance in the field and laboratory, D. Kennedy for Fig. 2. and Drs D. French and L. Sanford for their comments on an earlier draft. Dr L. Douglass provided guidance with statistical analysis. This work formed part of M.S. degree research by the first author in the Marine-Estuarine Environmental Science Program of the University of Maryland and was partly supported by a graduate assistantship from the Horn Point Environmental Laboratory. Contribution No. 2333 of the University of Maryland System Center for Environmental and Estuarine Studies.

\section{LITERATURE CITED}

Alexander, S. K. (1986). Diet of the blue crab, Callinectes sapidus Rathbun, from nearshore habitats of Galveston Island, Texas. Texas J. Sci. 38: 85-89

Blundon, J. A., Kennedy, V S. (1982a). Mechanical and behavioral aspects of blue crab, Callinectes sapidus (Rathbun), predation on Chesapeake Bay bivalves. J. exp. mar. Biol. Ecol. 65: 47-65

Blundon, J. A., Kennedy, V. S. (1982b). Refuges for infaunal bivalves from blue crab. Callinectes sapidus (Rathbun). predation in Chesapeake Bay. J. exp. mar. Biol. Ecol. 65: $67-81$

Charnov, E. L. (1976). Optimal foraging, the marginal value theorem. Theor. Popul. Biol. 9: 129-136

Creswell, P. D., McLay, C. L. (1990). Handling times, prey size and species selection by Cancer novaezelandiae (Jacquinot, 1853) feeding on molluscan prey. J. exp. mar. Biol. Ecol. 140: 13-28

Davidson, R. J. (1986). Mussel selection by the paddle crab Ovalipes catharus (White): evidence of flexible foraging behavior. J. exp. mar. Biol. Ecol. 102: 281-299

Ebersole, E. L., Kennedy, V. S. (1994). Size selection of the Atlantic rangia clam, Rangia cuneata, by blue crabs, Callinectes sapidus. Estuaries 17: 668-673

Eggleston, D. B. (1990a). Behavioural mechanisms underlying variable functional responses of blue crabs, Callinectes sapidus feeding on juvenile oysters, Crassostrea virginica. J. Anim Ecol. 59: 615-630

Eggleston, D. B. (1990b). Foraging behavior of the blue crab, Callinectes sapidus, on juvenile oysters, Crassostrea virginica: effects of prey density and size. Bull. mar. Sci. 46: $62-82$

Elner, R. W., Hughes, R. N. (1978). Energy maximization in the diet of the shore crab, Carcinus maenas. J. Anim. Ecol. 47: 103-116

Haddon, M., Wear, R. G., Packer, H. A. (1987). Depth and density of burial by the bivalve Paphies ventricosa as refuges from predation by the crab Ovalipes catharus. Mar. Biol. 94: 25-30

This article was presented by R. J. Feller, Columbia,

S. Carolina, USA
Hines, A. H., Comtois, K. L. (1985). Vertical distribution of infauna in sediments of a subestuary of central Chesapeake Bay. Estuaries 8: 296-304

Hines, A. H., Haddon, A. M., Wiechert, L. A. (1990). Guild structure and foraging impact of blue crabs and epibenthic fish in a subestuary of Chesapeake Bay. Mar Ecol. Prog. Ser. 67: 105-126

Hughes, R. N., Seed, R. (1981). Size selection of mussels by the blue crab Callinectes sapidus energy maximizer or time minimizer? Mar. Ecol. Prog. Ser. 6: 83-89

Juanes, F., Hartwick, E. B. (1990). Prey selection in Dungeness crabs: the effect of claw damage. Ecology 71 : $744-758$

Laughlin, R. A. (1982). Feeding habits of the blue crab, Callinectes sapidus Rathbun, in the Apalachicola Estuary, Florida. Bull. mar. Sci. 32: 807-822

Lin, J. (1991). Predator-prey interactions between blue crabs and ribbed mussels living in clumps. Estuar. coast. Shelf Sci. 32: 61-69

Linton, C. M. (1990). Predation techniques used by blue crabs, Callinectes sapidus, on bivalves, and effect of relative bivalve size on handling time. M.Sc. thesis, University of Maryland, Eastern Shore, Princess Anne

Lipcius, R. N., Hines, A. H. (1986). Variable functional responses of a marine predator in dissimilar homogeneous microhabitats. Ecology 67: 1361-1371

MíacArthur, R. H., Pianka, E. R. (1966). On optimal use of a patchy environment. Am. Nat. 100: 603-609

Mansour, R. A., Lipcius, R: N. (1991). Density-dependent foraging and mutual interference in blue crabs preying on infaunal clams. Mar. Ecol. Prog. Ser. 72: 239-246

Milliken, G. A., Johnson, D. E. (1984). Analysis of messy data. Van Nostrand Reinhold Co., New York

Parr Instrument Co. (1960). Instructions for the 1341 plain jacket oxygen bomb calorimeter Manual No. 147. Parr instrument Co., Moline, IL

Phillipson, J. (1964). A miniature bomb calorimeter for small biological samples. Oikos 15: 131-140

Pyke, G. H., Pulliam, H. R., Charnov, E. L. (1977). Optimal foraging: a selective review of theory and tests. Q. Rev. Biol. 52: $137-154$

Snedecor, G. W., Cochran, W G. (1980). Statistical methods, $7 \mathrm{th}$ edn. Iowa State University Press, Ames

Sponaugle, S., Lawton, P. (1990). Portunid crab predation on juvenile hard clams: effects of substrate type and prey density. Mar. Ecol. Prog. Ser. 67: 43-53

Tagatz, M. E. (1968). Biology of the blue crab, Callinectes sapidus Rathbun, in the St. John's River, Florida. Fish. Bull. U.S. $67: 17-33$

van Heukelem, W. F. (1991). Blue crab Callinectes sapidus. In: Funderburk, S. L., Jordan, S. J., Mihursky, J. A., Riley, D. (eds.) Habitat requirements for Chesapeake Bay living resources, 2nd edn. Living Resources Subcommittee, Chesapeake Bay Program. Annapolis, MD, p. 6.1-6.24

Virnstein, R. W. (1977). The importance of predation by crabs and fishes on benthic infauna in Chesapeake Bay. Ecology 58: $1199-1217$

Virnstein, R. W (1979). Predation on estuarine infauna: response patterns of component species. Estuaries 2: $69-86$

Manuscript first received: January 9, 1994

Revised version accepted: October 25, 1994 